\title{
Infrastructures of Reception: The Spatial Politics of Refuge in Mannheim, Germany
}

This article investigates the spatial politics at play in the urban reception of refugees by proposing an infrastructural conceptualisation of humanitarian spaces. In doing so, it destabilising the assumption that urban infrastructures form the mere backdrop of humanitarian government by thinking the city as socio-technical networks. By advancing the notion of infrastructures of reception, we draw attention to those parts of urban space that establish relationships between refugees and the cities that host them. Drawing on ethnographic material collected in and around a state-managed reception centre in Mannheim, Germany, the article advances a critical reading of the universal, humanitarian gestures the German state has employed towards migrants since 2015, juxtaposing the state's rhetoric with the actual spaces of refuge. An attention to the situated materiality of the reception centre and its policy framework uncovers on one hand that Mannheim's reception gesture towards refugees was the outcome of riskbenefit calculations and, on the other that its spatiality contributes to its residents' immobility, containment and suspension. Ultimately, the article argues that an infrastructural approach to urban reception practices offers a pertinent theoretical and methodological tool to uncover its political trajectories through highlighting the refugees' centre ambivalent relationship with the city.

Keywords: infrastructures; spatial politics; humanitarianism; refugee reception; Germany

INTRODUCTION

In 2015, the federal state of Baden Württemberg opened a refugee centre in 'BenjaminFranklin-Village' (BFV), a 144-acre former US military base at the outskirts of Mannheim, a city located in the south-western part of Germany. Parallel to it runs the much-frequented highway B38, which serves as one of the main arteries into the city centre, with a speed limit at $100 \mathrm{~km} / \mathrm{h}$. Traditionally, the separation effect this had on the surrounding neighbourhoods was not an issue because of the isolated nature of the military barracks from the surrounding 
neighbourhood. However, the highway's role changed drastically with the arrival of refugees in BFV. Due to the camp's isolated nature, with no commercial opportunities on the barracks' side of the highway and the only bridge being very difficult to access for pedestrians, it became a habit for residents to cross the highway into the adjacent neighbourhood. A dangerous practice that even caused the death of one resident in 2015 (Rhein-Neckar-Zeitung 2017).

Unexpectedly, the insular character of BFV was broken. Consequently, it was the municipality that had to react, reducing the speed limit to $70 \mathrm{~km} / \mathrm{h}$ (ibid.). The deathly

40 incident reveals the unmistakable connectedness of the centre with the city at the level of its urban infrastructure, suddenly demanding a synergy between the managing responsibilities of the federal state and municipal authorities. This illustrates that, while the state-managed reception centre comes into being through a denial of its socio-spatial connectedness to the city, thus appearing as if separate from the boarder socio-spatial contexts in which it operates,

45 it is actually deeply entangled with the city's urban networks. It highlights the collective nature of infrastructure, revealing how a denial of such de facto connectedness goes hand in hand with an abdication of responsibility, leading to harmful social, and even deathly consequences that could have been avoided if the refugee centre's effect on city-making would have been considered before. Concentrating on this spatial ambivalence of the centre,

50 disconnected and yet connected to the city, this article aims to investigate and reflect the nature of the relationship between refugee centres and urban space and thus contributes to an understanding of how humanitarianism is spatialized in Germany.

While migration studies have juxtaposed the universal promise of Germany's welcoming role in 2015 with the differentiating effect it held, elucidating how migrants are excluded from the 
nation state (Hess et al. 2016; Mattes \& Stadlmair 2017) or exposing how de-politicising discourses and discriminatory asylum measures go hand in hand with the humanitarian paradigm advocated by the German state (Pro Asyl 2015; Holmes \& Castañeda 2016; RibasMateos 2016; Schwarz 2016), they have largely ignored the role of space in creating such 60 ambivalence. If at all, space solely figures as a passive backdrop to the politics of refugee reception. Crucially, though, newcomers and the responding humanitarian system are shaping urban processes at different scales: to facilitate the new geopolitical order and to control the newcomers' entrance into the urban fabric, the state initiated the creation of hundreds of new reception centres, often located on the outskirt of cities in vacant facilities such as army

65 barracks, hotels and airports, and managed by government authorities.

In this scenario, the article intervenes into the debates about the ambivalent nature of the German reception system, arguing that the spatiality of reception centres (including their architecture, administration and government) is an active part of this ambivalence. It will do

70 so by drawing on the rising body of literature in urban studies and critical geography, which analysis the social life of a city through its material infrastructures 'by taking encounters between people and infrastructure as units of analysis and connecting them to illuminate how infrastructure shapes the social world' (Angelo \& Hentschel 2015:306; Amin 2014). We argue that this new thinking about urban infrastructure is particularly suited for the task of 75 discerning the spatial politics of refuge as it contends that they form an integral part of the conduct of politics (see for example Graham \& Marvin 2001; Graham \& McFarlane 2015). In doing so, our understanding of politics is guided by conceptualisations of government in the Foucauldian sense (Foucault 1984; Tazzioli 2015; Walters 2011), asserting that power operates spatially, or through spatial management, thus emphasising that all politics and state 80 power manoeuvres not just within, but is also shaped by space. 
We broadly construe infrastructures of reception as those parts of the urban fabric that establish relationships between refugees and cities that host them. We put this notion forward to focus on the reception process, rather than the arrival process of migration, as it has

85 increasingly been the case in recent studies on the impact of migration in urban settings (Meeus et a. 2018; Kreichauf 2018; Blommaert 2014; Saunders 2011). First, by focusing on the dynamics of the urban reception context, we want to draw attention to the multifarious local aspects that shape the reception experience of refugees in cities and impact the humanitarian government of migration. Second, we chose an infrastructural perspective on

90 reception processes because it opens fertile grounds for a critical reading of the ambivalent and complex nature of the position of the state in the management of migration. States produce and maintain governmental infrastructures that are at once supportive and exclusionary, creating movements for some, but containment for others (Graham and Marvin (2001). Drawing on Keller Easterling's work on the 'zone' and thus dissecting the territorial 95 ambiguity and splintering material conditions of the reception process, the authors show the fruitful lesson that can be learned from the emerging field infrastructure studies for the study of urban reception systems. The notion of infrastructures of reception thus highlights that the refugee centre's location, government and procedures affect the refugees' relation to the city in complex ways and in doing so, offers an opportunity to politicise and question the state's 100 humanitarian discourse of 2015.

The discussion is based on ethnographic material collected in and around BFV, comprising interviews and participant observation carried out between December 2016 and September 2017. In total, we conducted 15 semi-structured interviews with social workers, state 105 officials, urban planners and local politicians. To reduce bias, we aimed at including a wide 
range of voices and interviewed actors from different refugee organisations and chose institutional actors based on their responsibilities and roles in managing the centre. This material was combined with participant observation inside and around the reception centre in April and June 2017, which was possible through an internship of the first author with one of

110 the NGOs on site. The observations were used to complement the interview data and to achieve a deeper understanding of the relationship between the centre and the city.

The article is organised in two parts. The first outlines its theoretical dimensions, bringing critical writings on humanitarianism into conversation with new approaches to infrastructure,

115 generating a productive space for investigating the tensions between the humanitarian, universal promises of reception in Germany and the way its spatial politics may also render visible ambivalence and notions of separation, containment and suspension. This part also introduces the notion of infrastructures of reception, which is subsequently developed in the empirical section. The second part analyses data collected in Mannheim along two axes: on

120 one hand, it scrutinises the policy framework determining the German reception system and examines the urban processes that shape the practice of infrastructures of reception in Mannheim, specifically the transformation of the former military base. On the other hand, it investigates the socio-technical arrangements of BFV, illustrating the ambivalent nature of this humanitarian space and how it is governed.

\section{SPATIALISING HUMANITARIANISM}

Over the past years, a growing literature has emerged on humanitarianism (Rajaram 2002; Fassin 2007, 2012; Ticktin 2011; Oliver 2017), using it as a productive tool to uncover the specific developments, actors and practices of the humanitarian government of migratory

130 movements and borders (Agier 2011; Walters 2011; Tazzioli 2015). This literature holds that 
the 'humanitarian' not only constitutes activities of certain non-governmental actors and organisations, or a set of ideologies. Rather, it can be connected to a broader field of government as a rationalised activity, encompassing various actors in various contexts and to different ends. Fassin defines humanitarian government as 'the administration of human

135 collectives in the name of a higher moral principle which sees the preservation of life and the alleviation of suffering as the highest value of action' $(2007,151)$. He underlines that this broadened perspective offers the possibility to think humanitarianism as assembled complexity, including specific forms of reasoning, authority (medical, legal, spiritual) and certain technological forms of government, such as fundraising, training volunteers,

140 administrating aid and shelter, documenting injustice or announcing abuse. In this light, then, humanitarianism appears as a much more unstable and erratic thing. It allows to see 'a broader political and moral logic at work both within and outside state forms'(ibid.), which is never neutral and always political (Oliver 2017).

145 Concentrating on the spatiality of humanitarianism, Walters advances the idea of the humanitarian border, arguing that it comes into being when the 'exercise of humanitarian power is connected to the actualisation of new spaces' $(2011,139)$ at the borders of states. It is, however, not a fixed, stable entity, not a line associated with the political borders of a cartographic space, but more resembling of a technical zone, which comes into being when

150 'the qualities of objects or practices are assessed in order that they meet more or less common standards or criteria' (Barry 2006, 240). This is illustrated by a key action of NGOs, namely the examination of particular sites and reception practices in order to reveal to what extent they meet, or fail to meet, commonly recognised, or legally encoded norms and standards for the treatment of migrants and refugees (Walters 2011). It is, however, not our intention to 155 directly apply these insights from the study of national borders to urban spaces, as it is 
showcased by the literature on urban frontiers and borders (Sassen 2012; Lebuhn 2013; Fauser 2017).

Rather, we are concerned with how these dynamics play out in urban environments by

160 weaving them together with new approaches to the study of urban infrastructures. Taking critical writings on humanitarianism as a starting point, we are interested in the way it is spatialized between so-called reception centres and the cities that host them in the German context, as we believe it is crucial to study refugee reception within specific geographical, political and social contexts (O’Neill 2012; Janmyr \& Knudsen 2016). In the following part,

165 we suggest how we might begin to think the spatial elements of humanitarianism by approaching its political relations as infrastructural technologies.

\section{THEORISING INFRASTRUCTURES OF RECEPTION}

The new literature on infrastructure is abundant. Amin (2014) identifies three significant

170 ways in which recent works have opened the infrastructural 'black box' (Graham 2010a). First, by comprehending the city as a provisioning machine, secondly, by examining infrastructures' symbolic power and their social selectiveness and thirdly, by exposing how infrastructures are involved in the human experience in the city (Amin 2014:138-139). What all three strands have in common is that they view infrastructure not just as a static form that

175 constitutes a reliable and neutral backdrop of a political meta-structure (Barry 2016; Larkin 2013). Rather, they share an interest in how infrastructures influence urban social life by drawing infrastructure 'out of the background and into the foreground' (Appel et al. 2015). After briefly reviewing these three strands of thought, this section of the article particularly focuses on the latter two, highlighting the spatial ambiguities that arise in infrastructural 180 spaces and from that developing the notion of infrastructures of reception. 
First, as built networks, infrastructures constitute the physical form that enables the exchange of goods, people information and ideas over time and space. Thus, considering the city as provisioning system posits infrastructure as a site of contestation and negotiation over who

185 gets included or excluded, what is public or private. In this sense, they are not solely components of a technical urban process, but a crucial social dimension, essential to urban everyday life (Appadurai 2015); when they function, they provide us with the necessities of life (connections to others, food, water, sanitation, information, security etc.). But distributive infrastructures are themselves unevenly distributed, also prohibiting connections (Cowen

190 2017). As such, they also help endue the 'fragmentation of the social and material fabric of cities' (Graham \& Marvin 2001:3). Thus, 'infrastructure may entrench injustice in systems that seem technical rather than political, instead of techno-political and can thus serve to naturalise those relations' (Cowen 2017).

195 Secondly, with regards to the spatial politics of refuge in Germany it is particularly interesting to think infrastructures as material enabling of modern nation states, as symbols and practices of the government of populations and environments (Braun 2014; Harvey \& Knox 2012; Rodgers \& O’Neill 2012; Collier 2011; Dillon \& Reid 2009) that are used to legitimise interventions in the city and the displacement of residents (Gray \& Mooney 2011).

200 Amin \& Thrift see the city as 'a machine whose surge comes from the liveliness of various bodies, materials, symbols, and intelligences held in relation with specific networks of calculation and allocation, undergirded by diverse regimes and rituals of organisation' (2017:24). Infrastructure, they argue, 'does not refer simply to actual physical lineaments. It is also, on one level, caught up with the moments of standardisation, technical compatibility, 
205 professional rivalry, bureaucratic imperatives, regulatory competences and general dispositions which allow things' (ibid. 25; Collier 2011).

Thirdly, the new writing on infrastructure, whatever form or appearance it may take, examines the ways in which it shapes social identities in the city and implicates the human 210 experience in the city (Amin 2014; Tonkiss 2013; Simone 2012). This part of the literature distillates the way residents are affected and challenged if public services or urban utilities cease to work and the habits of improvising and everyday routines this might trigger (Simone 2004; McFarlane 2011). Other parts concentrate on infrastructure more as a sensory site, viewing infrastructure as aesthetics (Larkin 2013), which enables new experiences and 215 perceptions, transforming imaginations and forwarding powerful desires and dreams. They point towards the deeply embedded intermeshing of the human experience with the sociotechnical systems that surrounds them (Gandy 2005), theorising the human body as ontologically characterised by 'dependency on infrastructure' (Butler 2016), making infrastructure a prerequisite for any form of politics: a scholarly focus on infrastructures as 220 social relations reveals the politics of space; it exposes that infrastructure is lively (Amin 2014), constitutive of the city (Coward 2009) and a process of urban everyday life that also disables action and separates people (Graham \& McFarlane 2015).

What we are concerned with here is the way in which this thinking about infrastructure may highlight the spatial ambiguities that arise in humanitarian spaces such as reception centres for refugees. In order to grasp how the centre is in but apart from the city in physical, social and political space, we find Keller Easterling's work on infrastructure as 'zone' particularly significant. Easterling opens the multiple strata of 'infrastructure space' as the "interplay between spatial variables to leverage the politics of the extrastatecraft" (2014:16), a powerful 
230 analytical neologism that unveils the "difference between the declared intent and an underlying disposition" (ibid.:32). Infrastructure space gathers the administrative powers of both state and non-state actors, driven by irrationalities and suspicious aspirations and thus produces clandestine forms of polity, sometimes at odds with domestic laws such as labour or environmental regulations, but a powerful weapon to the most powerful people on this planet.

235 Given the splintered materiality of the places she analyses, namely free zones, broadband in East Africa, and ISO's quality management and the territorial ambiguity that arise from it, she makes "an important diagnostic in the fluid politics of extrastatecraft, disposition uncovers accidental, covert, or stubborn forms of power-political chemistries and temperaments of aggression, submission, or violence — hiding in the folds of infrastructure 240 space" (ibid.: 129).

Therefore, we can begin to throw light on the spatial politics of refuge through an infrastructural lens. How might we think differently the promise of humanitarianism assigned to urban reception infrastructures by the German state? And, thus, what insights do we gain 245 about their inherent power relations by zooming in and examining the seemingly mundane, socio-technical practices of their formation and use? We suggest to explore these questions through the notion of infrastructures of reception. This framing builds on two key aspects of the literature explored above, namely the conceptualisations of infrastructures as symbols and practices of governments and as space and disposition of the human experience in the city.

Continuing with Easterling anaclitic at work here we might draw a fertile parallelism between refugee reception centres as humanitarian dispositive and Easterling's free zone. At the centre of this parallelism lies the political ambivalence that becomes tangible in both infrastructural spaces. Firstly, Easterling draws our attention to the (il-)legality of these infrastructures: "a 
255 legal and economic instrument, the zone presides over a cocktail of enticements and legal exemptions that are sometimes mixed together with domestic civil laws, sometimes manipulated by business to create international law, and sometimes adopted by the nation in its entirety" (2016:51). Second, she parses out the contradictions between the political and physical language promoting the spatiality of the zone as 'openness, relaxation,

260 and freedom', countered in reality by what is often the opposite of hyper-control and segregation: 'as the contemporary entrêpot of the planet's resources, the zone, despite efforts to be apolitical, is now in the crosshairs of pirates, terrorists and traffickers'(Easterling 2012). Lastly, Easterling views the zone as central, rather than peripheral. Tracing the long history of such zones and their spread into other 'enclaves' (ibid.), she stipulates that wat they have

265 in common is a detachment from national politics on one hand, and on the other a connection into global trade and communication infrastructures.

Turning to the micro level of reception centres by treating them as infrastructures thus allows investigating their 'capacity to enchant' (Harvey \& Knox 2012, 522) with respect to

270 welcoming gestures and care and can expose the ambiguities that it holds. Seeing like infrastructure, the spatiality of reception infrastructure and what they $d o$ to its subjects - is an exercise related to various scales, actors and strata of powers. In doing so, it may become clear that the state's abstract and technical discourse, attempting to frame the capacity of reception centres, does not suffice to explain the promise of the state's humanitarian

275 paradigm. In the next section, the case of Mannheim offers an opportunity to develop these ideas. But before turning to the site specifically, the paper outlines the context of the German asylum system, which the reception centre is embedded in. 


\section{CONTEXTUALISING RECEPTION PRACTICES}

280 Two elements are crucial in defining the context of refugee reception in this paper: firstly, the socio-spatial impacts of national asylum laws and policies and secondly, the chosen case study, namely the city of Mannheim, revealing several urban layers decisive for the way in which infrastructures of reception are practiced, namely: the US army's departure from BFV, the municipality's development plans for the site and of course the refugees' arrival itself.

Upon arrival via land or air, refugees are registered at any of the closest reception centre and subsequently proportionately distributed across the federal states of Germany following the Königssteiner Schlüssel, a specific quota system for allocating refugees according to tax revenues and total population of the respective Federal State. ${ }^{1}$ Such spatial organisation of

290 reception already recalls a Foucauldian notion of government, contending that spatial distribution is vital in sustaining sovereignty, whereby the relation between sovereignty and territory aims 'to connect the political effectiveness of sovereignty to a spatial distribution' (Foucault 2003, 15-16 in Boano 2011, 7).

295 While the national government holds responsibilities for providing overall legislation on asylum, the 16 federal states hold the competences in providing accommodation and covering basic needs. As they have traditionally resolved the issues of reception through different measures (e.g. accommodation standards, support on site) reception facilities can vary significantly ${ }^{2}$. Generally, centers can be categorised following a two-tire system. Firstly, 300 asylum seekers are accommodated in initial reception centres (Erstaufnahmeeinrichtungen, EAE), such as BFV in Mannheim, managed by federal states (see figure 1). Secondly, they are transferred to communal centres or decentralised accommodation, which are in turn

\footnotetext{
${ }^{1}$ For a detailed analysis and critique of the system see: Geis \& Orth (2016) and Katz et al (2016).

${ }^{2}$ Take, for instance, the variety regarding required living space. In Baden-Württemberg, an asylum seeker should have 4.5 $\mathrm{m} 2$ living space, while other regulations provide 6 or $7 \mathrm{~m} 2$ per person (Müller 2014:26).
} 
administered by municipalities. One of the EAE's most obvious infrastructural capacities is therefore to move and distribute people. EAEs are usually the place where asylum

conditions, sheltering at least several hundred places, depending on the capacities of available sites, legislation and intake (Wendel 2014, 64; Müller 2014; Aumüller 2015).

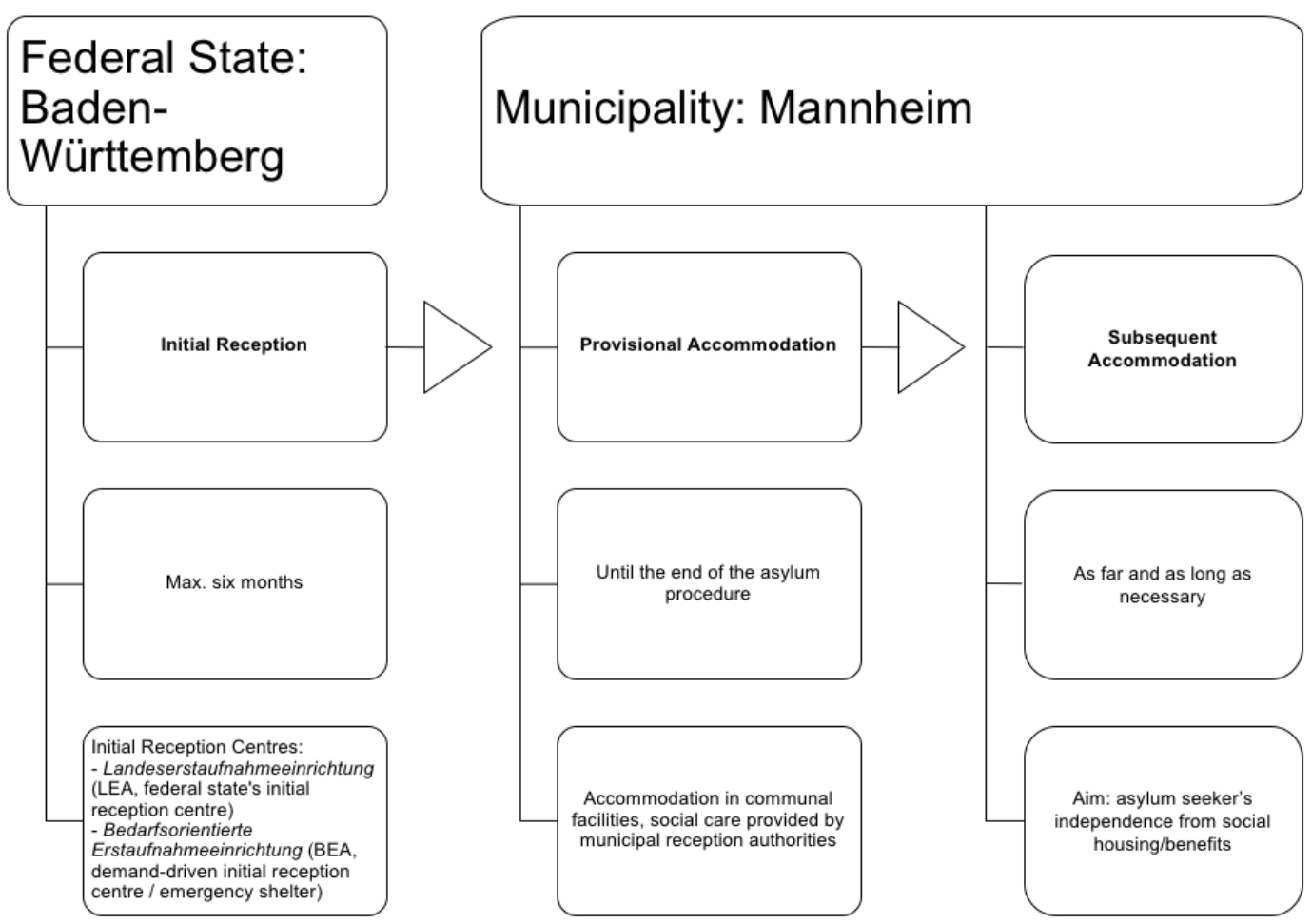

However, as this research project focuses on an EAE, it is important to note some changes in policies regarding initial accommodation, essentially immobilising asylum seekers. Indeed, they render evident how movement and the control of populations are integral elements,

315 underlining the nexus of migration and government in that it emphasises that control over mobility serves as strategy for containing ‘dangerous' displacements (Tazzioli 2015:160). In October 2015, a new national asylum law was passed, reintroducing the deterrence measures 
applied in the 1990s, when Germany experienced its last substantial increase of asylum seekers following the civil war in Ex-Yugoslavia (Pichl 2016, 163).

During the stay in the EAEs, asylum seekers are not allowed to work, and only receive noncash benefits in many federal states, though cash in Baden-Württemberg. If asylum seekers already have family members living in Germany, they may not move close to them. Further, victims of abuse or vulnerable refugees, like women or children, are equally obliged to stay in EAEs (Pichl 2016). Further, the immobility of asylum seekers is enhanced through an extension of a residence obligation, requiring asylum seekers to remain in an assigned district and federal state. Such denial of freedom of movement had previously been abolished in 2014, but has now been re-introduced. In case the asylum seeker leaves the assigned district without authorisation, a fine of 2,500 Euros can be charged. In case of a second offence, a one year prison sentence is possible. ${ }^{3}$

This is a particularly relevant measurement in Mannheim, situated in the tri-border region between Rhineland-Palatine, Baden-Württemberg and Hesse. Analysing BFV's embeddedness into other urban infrastructures, it is pertinent to note that the tram stopping right in front takes 13 stops to Mannheim's city centre and only one stop to a big shopping mall in Viernheim, the neighbouring city in Hesse. However, representatives of the state repeatedly stressed that it was absolutely prohibited to travel to Viernheim (Interview 001) ${ }^{4}$. Actually taking the tram, conversely, one notices many residents also taking the journey, thus

\footnotetext{
${ }^{3}$ Further immobilising measures were implemented: Following the new Integration Act (July 2016) a domicile requirement for municipalities was introduced. It is linked with social benefits, meaning that already recognised refugees who are on social benefits cannot choose their place of residence. Currently, the domicile requirement is only implemented by the states of Baden-Württemberg and Bavaria. Lastly, in February 2016, the 'Asylum Package II' was passed, further tightening asylum legislation. It introduced 'special reception centres' in which asylum seekers from 'safe countries of origin', second applicants and refugees who either destroyed their documents, or are assumed to have done so, can be kept to 'accelerate asylum procedures'. Only two of them have been established in 2016 in Bamberg and Manching/Ingoldstadt (Kalkmann 2017:71).

${ }^{4}$ All interviews have been anonymised and numbered. Translations from German into English for quotations were done by the authors.
} 
crisscrossing the state's discourse on the federal border. Thus, thought infrastructually, the

one advocated by law, crisscrossing its administrative regulations through tolerated, illegal practices. This is confirmed by a comment by a NGO official on site:

'Everyone know that that's not possible, that they [the refugees] are not allowed to do that... and everyone does it. And why should I prohibit taking the tram for one station? No, no...that doesn't make sense. Then that's how it is and they spend one day in the "wrong" federal state. So what?' (Interview 007)

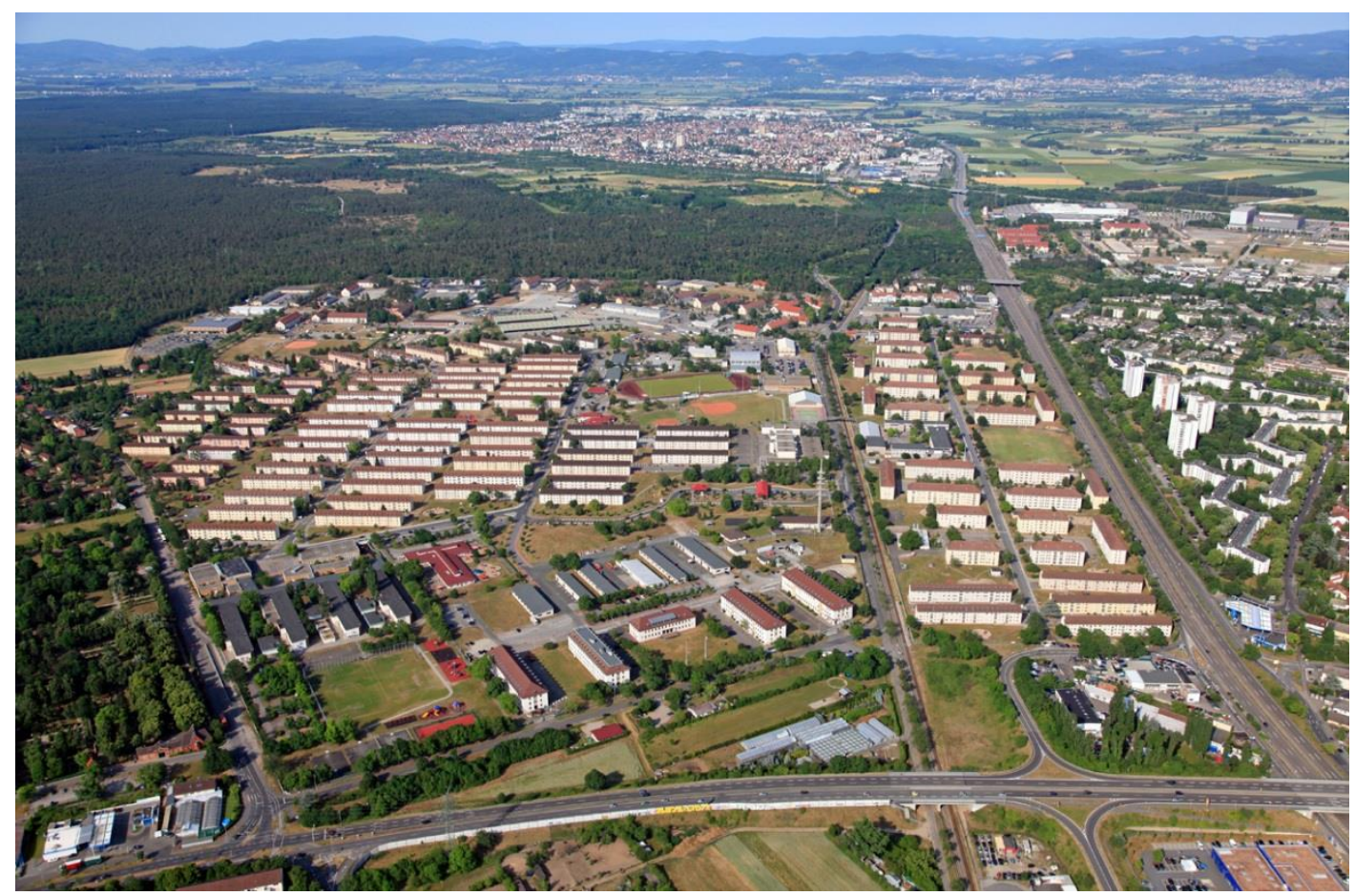

Figure 2 Areal View of Benjamin Franklin Village (BFV). Source: Kay Sommer

\section{The case of Mannheim}

Mannheim has played a pivotal role in the reception of migrants since 2015 (The Guardian 2016). With population of approximately 305,000 inhabitants, it is a mid-sized city, situated in the north-western corner of Baden-Württemberg, a federal state in the south-western part of Germany. It is located at the confluence of the two rivers Rhine and Neckar. The city's location between three federal states turned out to be vital in our research, as by law asylum seekers are not allowed to leave their assigned federal state and BFV is located only 500 
meters to the Hessian border, rendering the possibility of free movement for its inhabitants very limited, as stated above.

In the region, Mannheim is commonly known as the 'square city', referring to its baroque grid plan. More importantly, it has a long history of migration into the city, not last since receiving many 'guest workers' from Greece, Italy, Turkey and Ex-Yugoslavia in the 1960s, turning it into a city in which $44 \%$ of the population has a migrant background today, ${ }^{5}$ thus representing the specific historical experience of migration in Germany (Ehrkamp 2005). Since 2015 it has taken on a new role: its central station has served as a 'turnstile" ${ }^{6}$ from September 2015 until mid-2016, with more than 80,000 refugees arriving on special trains via the Balkan route. While most did not stay in the city but where distributed across other regions, at peak times in this period around 15,000 were sheltered in Mannheim (The

370 Guardian 2016). This was possible because of three vacant, former US-army barracks (Spinelli Barracks, Hammonds Barracks and BFV), which form a fifth of the entire city area and which were laid claim to by the federal state of Baden-Württemberg to shelter incoming refugees.

\footnotetext{
${ }^{5}$ For more information see: https://www.mannheim.de/de/stadt-gestalten/daten-und-fakten/bevoelkerung/einwohnermitmigrationshintergrund [accessed 20/07/2017].

${ }^{6}$ For more information see: https://www.mannheim.de/de/presse/fluechtlingszuzug-in-vergangenen-wochenstarkabgenommen [accessed 20/07/2017].
} 


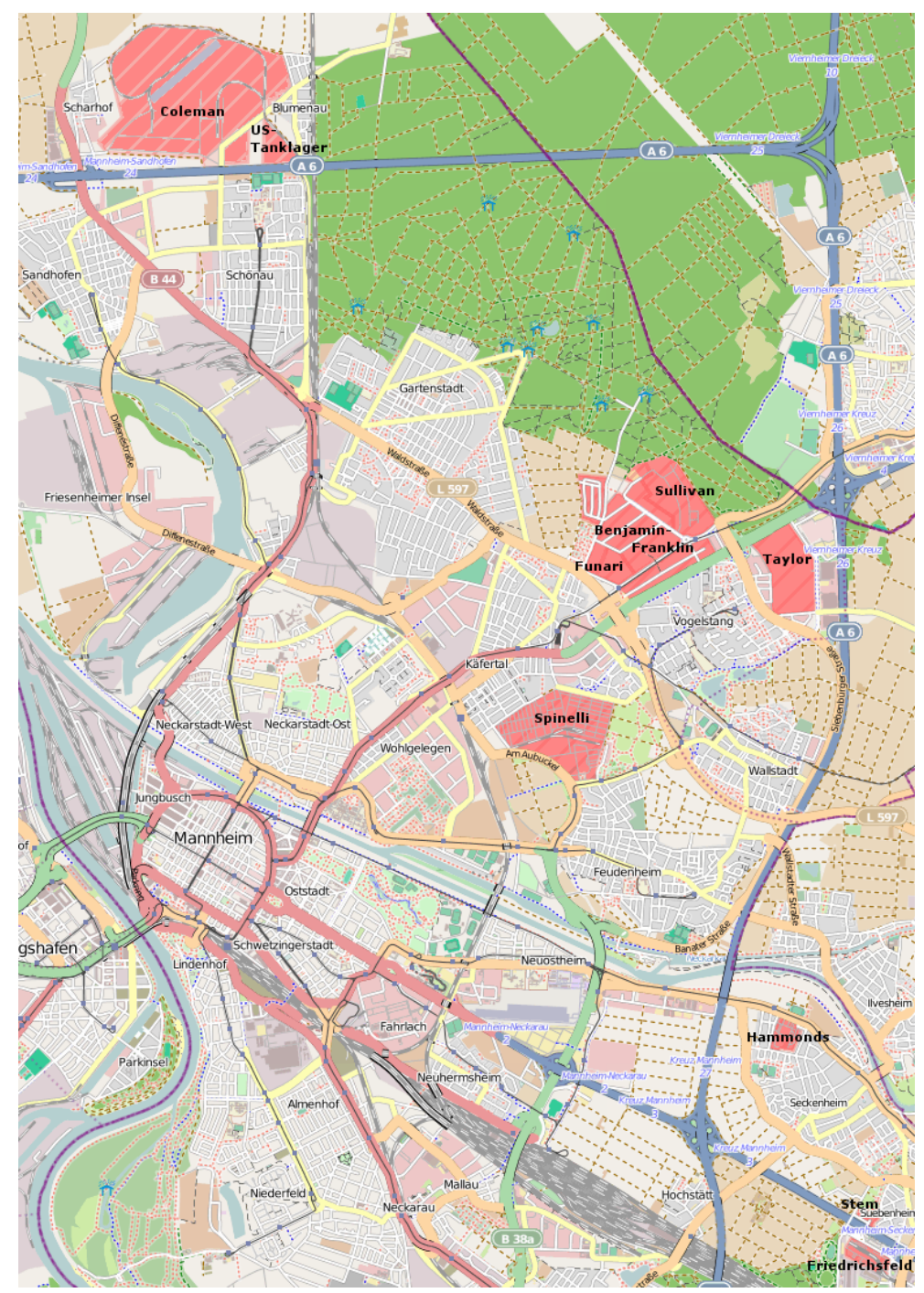

Figure 3: US-Military Bases in Mannheim. Source: Open Street Map 2018

BFV constitutes a particular case as it had been due to be sold to local investors and had been planned for some years to be converted into a new modern living district. Up until this day, however, it constitutes a so-called 'initial reception centre' (Erstaufnahmeeinrichtung, EAE), managed by the state of Baden-Württemberg. Accordingly, BFV is a suitable site to trace the spatial politics of reception infrastructures. It holds a series relatively established networks, as it was one of the first centres established in 2015.

385 Beginning from a range of four different centres, BFV was chosen as ethnographic field site mainly for a logistical reason, as it proved very difficult to negotiate the accessibility to other 
centres. Having contacted the administration of all four of them via e-mail, two of them did not response, a third replied that due to the huge press inquiries they do not grant entry for researchers. This left us with Mannheim, where a spokesperson of the state of BadenWürttemberg invited the first author for a first visit of BFV in April 2017.

A difficulty we faced, however, was to access BFV independently and for a prolonged period (Agier 2011). Highly securitised, BFV is surrounded by barbed wire and only has one entrance, where everyone entering is checked and searched (this applies to refugees living 395 there, as to visitors alike). During the first visit that had been arranged with state representatives, the first author was picked up by a security guard at the entrance and driven to the state's office by car. While walking around the barracks, she had one representative on each side, checking carefully where she took pictures and which questions she asked. Concerned about how this would constrain the research, she approached one of the NGOs working on site, Freundeskreis Asyl e.V. (FKA), offering counselling and legal advice for refugees, and was offered to intern with them for a period of three weeks. ${ }^{7}$ Together with a branch of the German Red Cross, it was the only NGO working on site. ${ }^{8}$ In addition, volunteers and social workers employed by the municipality had just opened a primary school in the centre when fieldwork started. This allowed to engage with the socio-technical settings of the site more independently. She was given an FKA identification plaque, which

\footnotetext{
${ }^{7}$ Volunteering with FKA involved running daily errands for staff members, distributing flyers about their work among residents, translating or running their reception desk on days when FKA was under-staffed.

${ }^{8}$ Access to NGOs is highly dependent on the place of residence. In some reception centres, welfare organisations or refugee councils have regular office hours or are located close to the centres so asylum seekers can easily access the offices of such organisations. However, offices of NGOs do not exist in all relevant locations and in any case, access to such services is not systematically ensured (Kalkmann 2016). In many 'arrival centres' access to NGOs is even more difficult, as there are not always established structures of NGOs that exist in the town or region where the new offices are located. The state of BadenWürttemberg forms an exception, where a law from 2014 (Flüchtlingsaufnahmegesetzt, FlüGA), outlining the guidelines of initial reception, states that every asylum seekers is entitled to qualified social and procedural counselling at initial reception centres (ibid.)
} 
privileged her as she, for example, could enter the site without having to show her passport and walk around freely.

\section{$\underline{\text { Three Urban Layers in Mannheim }}$}

Following WWII, Mannheim served as garrison for the US army's highest-ranking air

410 defence headquarters in Europe. Complementing the logistical sites, BFV was built in the 1950s as a residential area, encompassing approximately 2,000 housing units. ${ }^{9}$ The settlement maintained self-sufficiency from the city of Mannheim, including schools, hospitals and supermarkets, electricity and water networks. According to the planning office, it was out of fear that the local population might turn against them that the US army did not connect its

415 networks to the local grid (Field notes, 15 May 2017). This infrastructural peripherality of the site was crucial in the construction of the reception centre, as for weeks after its opening plumbing was not connected to the city's public networks, leaving the centre without any proper sanitation facilities (ibid.).

420 Historically, the site's isolation was strengthened drastically on the $9^{\text {th }}$ of September 2001. $\mathrm{BFV}$, which had previously been freely accessible to the German public, was sealed off from the local population: a second line of barbed wired fences, barricades and check points were installed as units from the Mannheim base served in military operations in Afghanistan and Iraq, evoking stark connections between the security politics in domestic cities and the

425 frontier war zones (Graham 2010b, 202). Indeed, BFV constituted a 'quasi gated community, practically non-existing in society over the last decades' (Bundesstiftung Baukultur 2017) until its closure in 2012. Consequently, it is this highly securitised, peripheral military state space, a first urban layer, into which a humanitarian space was carved in 2015, illustrating

\footnotetext{
${ }^{9}$ For more information: http://franklin-mannheim.de/franklin/geschichte [accessed on 24/08/2017]
} 
how the interlocking of the securitisation of borders and humanitarianism is rendered tangible 430 in space.

The moment the US army leaves Mannheim constitutes a second layer. When the working of the military base is disrupted, suddenly it 'become[s] a great deal more visible, politically and culturally' (Graham in Farias 2010, 198; Leigh-Star 1999), opening an important entry point

435 to excavate the politics of urban life (Graham 2010a, 3). What had previously been perceived by the local population as 'no man's land' (Niemansland Film 2017), now turned to the city's centre of attention. Indeed, a municipal development company was specifically created to plan the conversion and sell the new development to investors. For the Columbus Quarter in the Southern part of BFV, where refugees are sheltered, a large commercial site was planned,

440 hoping to generate growth in competition with the neighbouring federal state Hesse (Interview 005).

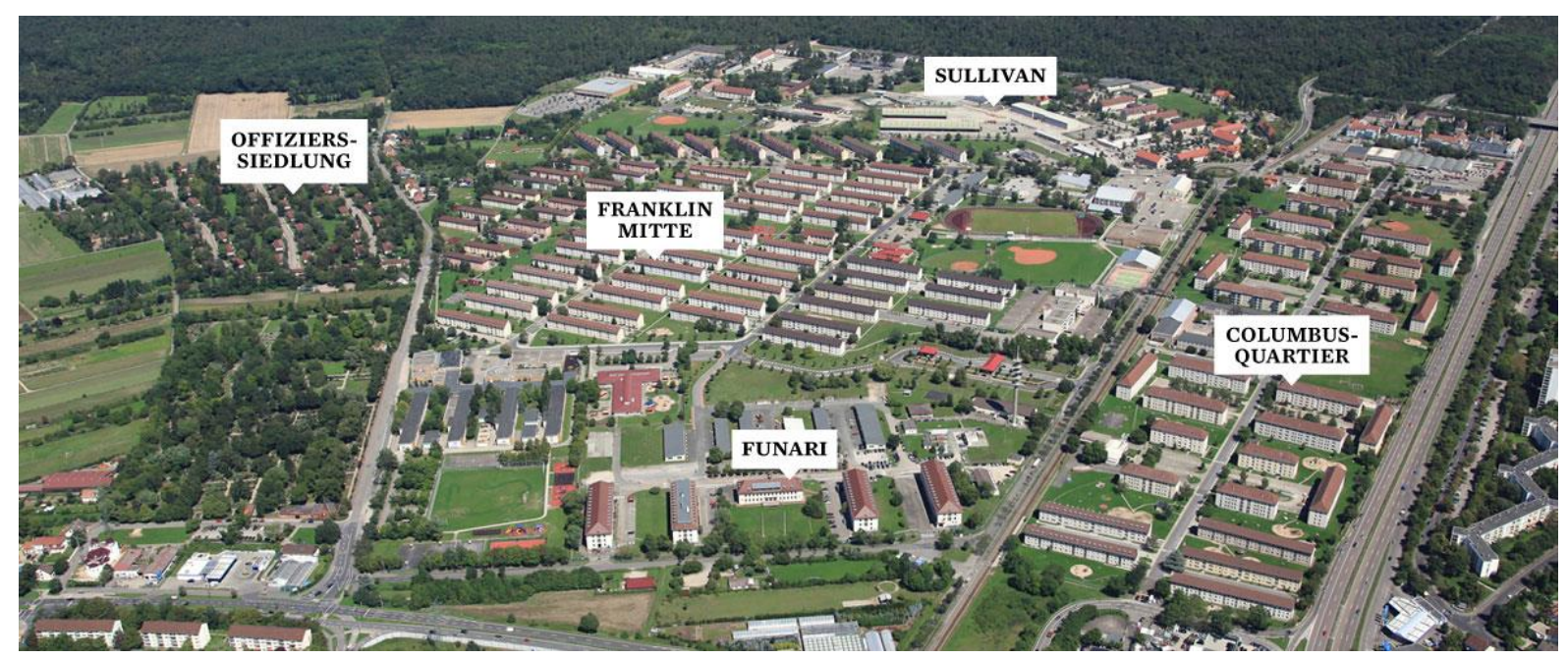

Figure 4 Subdivision of BFV. Source: MWPS

445

However, with the refugee's arrival, a third urban layer falls into negotiations between the city and the federal government, as the latter holds land ownership rights over BFV. When 
the federal state puts a hold on the purchasing negotiations, its decision to house 1200 refugees in BFV seemingly came as a surprise to the city of Mannheim. According to the major it would be a 'great challenge' for Mannheim but that 'we stand by our responsibility to help these people' (Stadt Mannheim, 14 October 2015).

Yet, while a humanitarian discourse emerged, it was immediately juxtaposed with the logic of calculations (Oliver 2017). That is, conversations with two senior officials revealed that the decision to shelter refugees in Mannheim was the outcome of a deal that secured the land ownership of the former military base for the municipality after the temporary accommodation of refugees and allowed for the beginning of constructions in some areas while the refugees were housed there. Locating an EAE in Mannheim ultimately means a relief for the local municipality. That is, if a city in Baden-Württemberg is hosting an EAE, it is exempted from the regular quota system of municipal accommodation of refugees. Without the EAE, Mannheim would have to accommodate 3000 refugees permanently and would also be responsible for integration measures such as language classes and social benefits (Interview 004). Further, the deal gave considerable leverage to the city of Mannheim for shaping the urban plan of the site:

'So that was very unusual for German standards [planning laws]: when it is about refugees, all of the sudden, with a hand stroke, you can have designated industrial areas, residential areas, you can have anything in the world...eh...all of the sudden everything works. I would never have dreamt that something like that would work in Germany. Because we had been discussing the status of a house on Franklin [BFV] for a long time. By law, there were no houses [...] the site allocation development plan said special area: barracks. It was not a civilian house, it was a military one.' (Interview 006)

In this vein, it can be argued that the reception gesture of the city of Mannheim was the product of risk-benefit calculations, based on the disadvantage or advantage refugees might bring to a process of re-making urban design in BFV. This calculation is materialised through 
the political construction of the group identity 'refugee', thereby enabling 'policies that treat refugees as collateral damage or units of exchange [...] rendering the lives of refugees fungible and therefore ultimately disposable' (Oliver 2017, 15). Oddly, then, in the logics of 480 the German reception system, receiving more refugees means receiving less refugees for Mannheim.

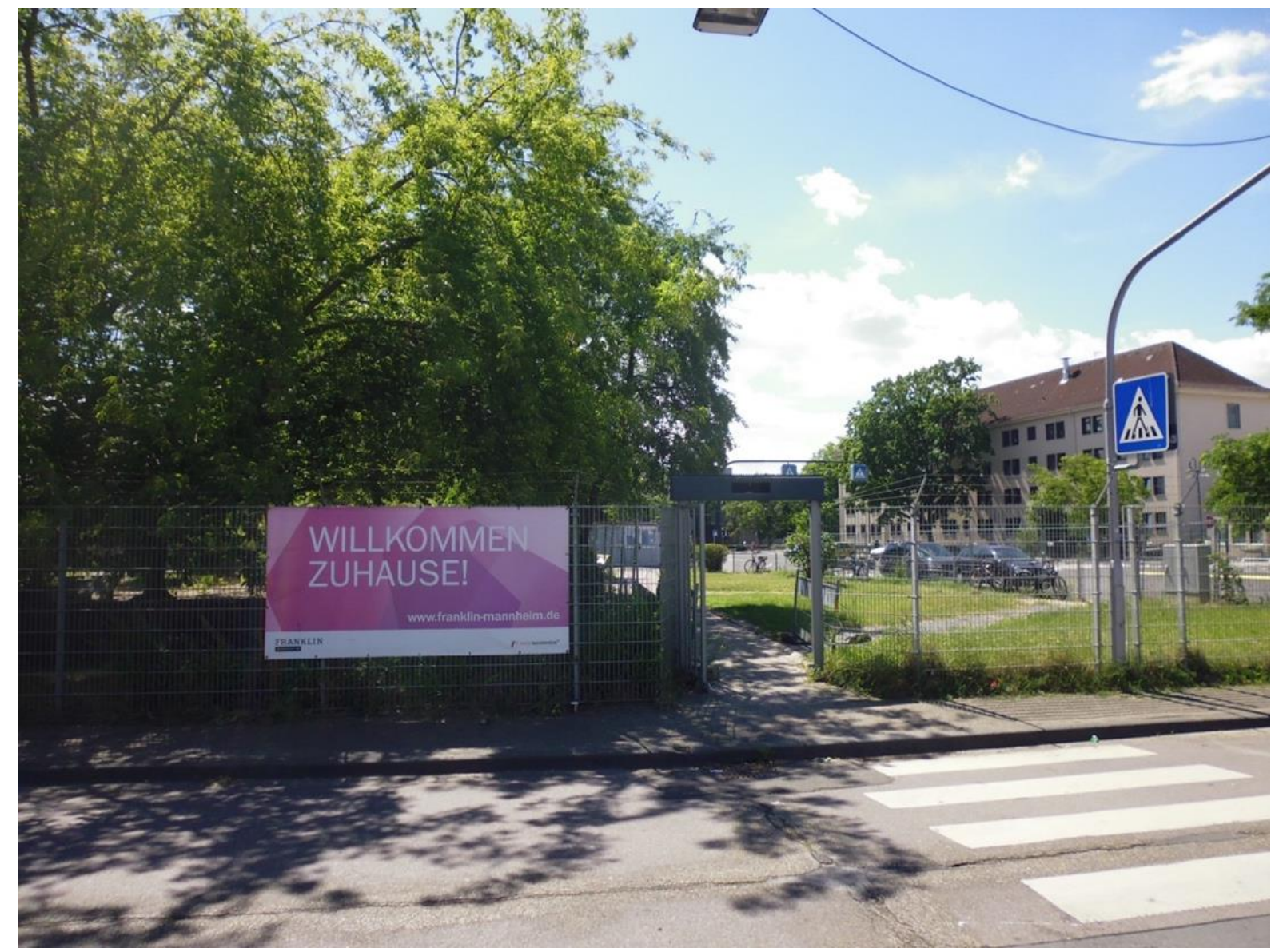

Figure 5: Advertisement at the entrance of the reception centre with the slogan 'Willkommen zuhause!' (welcome home. Curiously, it is owned by the municipal development company, aimed at potential invesotrs, not the current residents of $B F V$. Source: the authors

\section{INFRASTRUCTURAL POLITICS: THE SOCIO-TECHNICAL ARRANGEMENTS}

\section{$\underline{\text { OF BFV }}$}

So far, we have addressed the way policy, national governmental techniques and the

490 transformation of the military barracks shape the practice of reception infrastructures in

Mannheim. Successively, we turn to analyse the ethnographic materials generated on site, 
reimagining infrastructures of reception as central element in the conduct of the spatial politics of refuge by turning to the micro scale of the centre's socio-technical settings, exposing the ambiguity and inherent power relations of humanitarianism. In this part of the

495 paper we wish to show at first how BFV can be scrutinised as a space of humanitarian government. Secondly, we examine how it simultaneously enables and disables movement. Thirdly, we illustrate how the state-managed centre is disconnected and yet connected to the city, forging a double spatial urban logic.

\section{$\underline{\text { A Space of Humanitarian Government }}$}

500 To analyse how the power relations of a humanitarian space come into being, we crystallise how its governance is practiced and experienced (Agier 2010:36). The built environment characteristics of BFV render visible an urban mono structure, organised around six Ushapes. Wide green areas and playgrounds dominate the open spaces and a large boulevard leads through the entire complex, holding the space together, and serving as main access

505 avenue to all residential buildings. The managing NGO's and state offices are located in former public buildings such as the high school. 


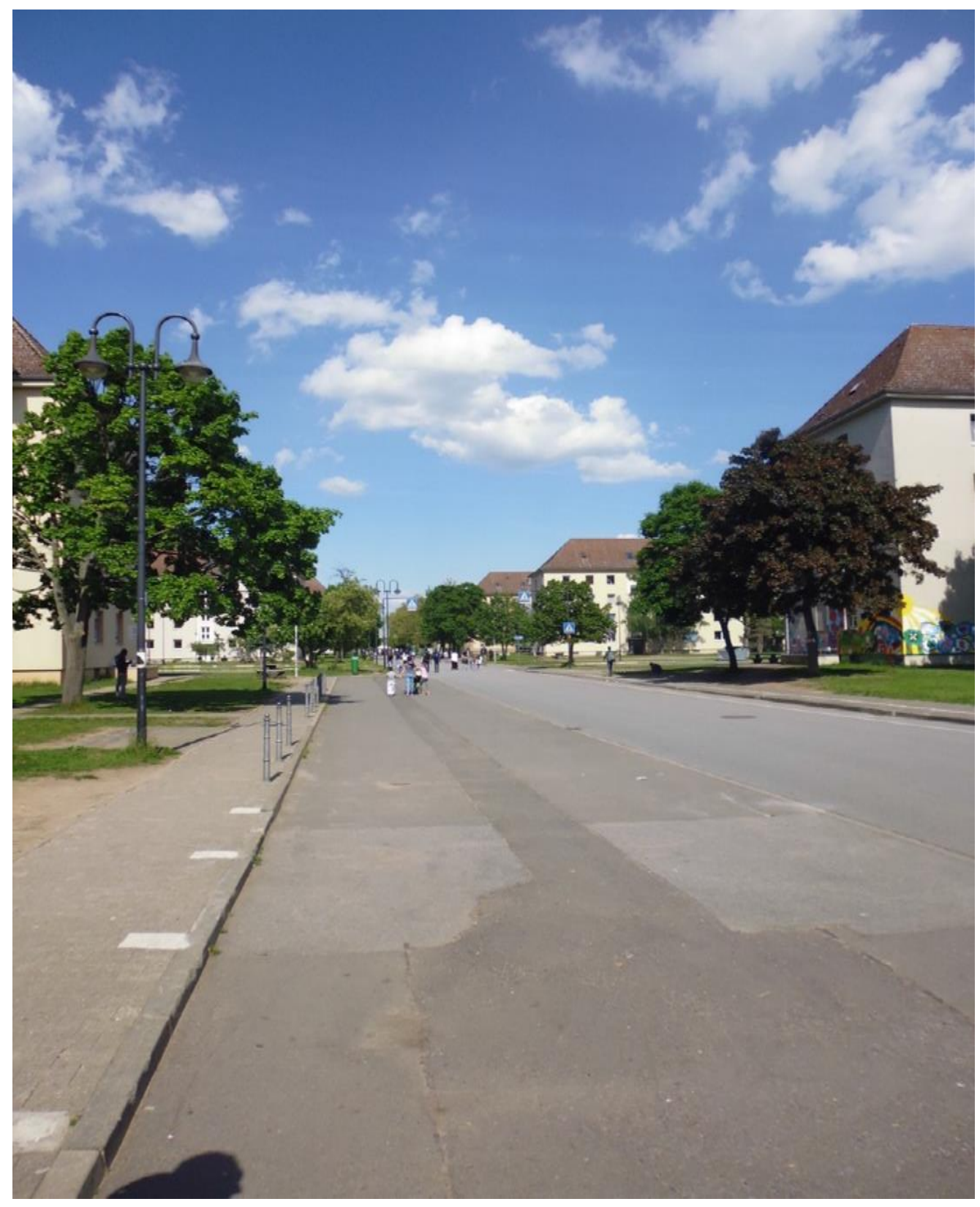

Figure 6: Main boulevard. Source: the authors

510 However, attending to the site ethnographically reveals that these technical aspects do not suffice to understand its socio-political components. Politics is neither prior to, nor determined by the material structures of space; rather it emerges through affective engagements with their materiality, becoming meaningful through the relationship it holds with specific social process (Knox 2017; Bevan 2006). Thus, focussing more closely to the 515 resident's affective engagements with the material arrangements of the site generally 
divulged very negative connotations. A comment from a resident, who has been living in BFV for almost twelve months, illustrates this:

'inside there, my body feels in a different mood [...] I want to stay outside for as long as I can.' (Field notes, 20 June 2017)

520 He points towards the unease he feels in the reception centre, noting how the space of BFV is affecting his mind and body by clearly differentiating between inside and outside. This is substantiated by a reflection from a social worker:

'Sure, the place here is not just physical. It is especially the emotional and mental elements which make this place what it is. What people feel and think...Yes, there're quite a lot of green spaces and old playgrounds, people have an actual roof over their head and don't live in tents, as it was often the case. But what counts in the end is what happens in their minds.' (Field notes, 23 June 2017)

Inquiring about the cause of such unease, informants pointed towards the government of the space. That is, focusing more closely reveals that the material consolidation of BFV is routed 530 in restrictions and control, constructing a daily life with multiple constraints.

The humanitarian government of the space is illustrated by the way in which a 'zone of qualification' (Barry 2006; Easterling 2012) is at stake in BFV, managed in such a way that it meets particular standards for the treatment of migrants and refugees, implementing a strict regime of regulations and control ${ }^{10}$ : no sharp objects and electronic devices are allowed on site apart from mobile phones, cooking is prohibited, doors cannot be locked and residents are checked with a metal detector upon entry and exit. The following comment by a social worker thus indicates the consequences for the lives of residents of this practice of control: If you get out of Gambia, and you manage to cross the Sahara, to collect money, and the people, your family trust in you. Then you survive Libya, you cross the Mediterranean,

\footnotetext{
10 This is according to $\S 6$ of the refugee admission law. For the full legislative text see: http://www.landesrechtbw.de/jportal/;jsessionid=AE93D045D27C7BEFAFCE7585C35C89DA.jp81?quelle=jlink\&query=Fl\%C3\%BCAG+BW\&p

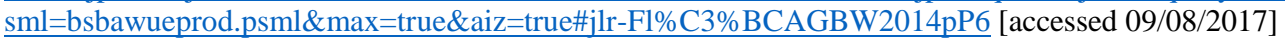


you manage to come here via Italy...that's an achievement. And then you get sedated here. Yes, you are being accommodated, but you cannot do anything by yourself. While before you were everywhere on your own, now it's the exact opposite. You are provided with food, but you cannot decide what you eat. You get an apartment, it's quite nice, but you cannot even put up a picture. If you decide to build a closet, you are not allowed to lock it. [...] It [the camp] is like a tranquiliser, isn't it? (Interview 005)

The comment reveals the paradox of the place that simultaneously protects and cares for its inhabitants and 'tranquilises' them, hindering a self-determined life. Crucially, then, this reaffirms that 'space is fundamental in any form of communal life; space is fundamental in any exercise of power' (Foucault 1984, 252), whereby urban design and architecture form powerful technologies, creating spaces that are not solely functional, but eminently hierarchical. That is, the humanitarian government of migrants in BFV follows a specific spatial strategy, shaping the manageability of collective formations. For instance, in addition to the restrictive measures discussed above, national groups are clustered together upon arrival and distributed across the blocks, constituting measures of spatial segregation that render the heterogeneous migrant composition governable (Brighenti 2014).

According to a state official in charge of monitoring the facilities on site, restrictions are legitimate because 'here, security is of greatest priority' (Field notes, May 2017). He adds:

560 'because they would often forget to turn the gas off, or let the water running...you have to be careful: they do not see the risk potential' (ibid.). The extensive control of residents is thus framed as necessity in the name of security, rendering them a homogenous mass, not capable of using ovens and water pipes, that for its own good needs to be governed strictly. Additionally, restrictions are justified with the explanation that, by law, people are only 565 staying at the centre for up to six months. However, most residents encountered during fieldwork have been living there for much longer, usually around twelve months. This again 
challenges the state's discourse on the reception of migrants, particularly with regards to the news asylum laws (see above), deceptively introduced to speed up the asylum process.

570 Thus, the socio-technical arrangements of BFV provide a good understanding of how humanitarianism is actualised in urban environment, rendering evident those specific forms of 'humanitarian reasoning' (Fassin 2012), which form the space of humanitarian government that is BFV.

\section{$\underline{\text { Control by Movement }}$}

575 The second element through which the ambivalent nature of infrastructures of reception is rendered visible is the way in which it manages the movement of its inhabitants. That is, although the reception centre contains people for prolonged periods of time, it does so while simultaneously enforcing mobility within the reception system, functioning as a 'sorting office' (Agier 2010, 35), designed to channel, retain, deport or re-direct people.

Katz (2017) has argued that the ongoing, internal mobility within the camp infrastructures facilitates control of individuals that are processed and held within it. Further, in the case of BFV migrants are rendered highly mobile through considering them merely as biological bodies, stripped of particular identities, only gathered together according to the next

585 destination point, or in other words they are 'grouped in order to be managed and controlled, and at the same time they are grouped to be divided' (Tazzioli 2016, 2). This is exemplified by a comment of an NGO official, comparing the residents to a herd of cows:

'It sounds very harsh, but it's just like moving 500 cows from farm $X$ to farm $Y$ and back to farm X, only to take them back to farm $Y$. We've had that too. We've had a family here, they lived here [...] and they were transferred to Mannheim from Karlsruhe. [...] Didn't they actually have to go on the bus [to Karlsruhe] and then had to come back here because they were transferred into communal accommodation [in Mannheim]?' (Interview 007) 
The comment illustrates that BFV itself is embedded into a larger system, a network of

reception centres that are connected with each other, facilitating the senseless movement

of refugees through this system and in doing so disrupting any social relation that could be built by staying within a familiar environment. Further, it alludes to the arbitrary nature of the German two-tire dispersal system, creating a double-edged nature of migrant management, which objects any spatial logic by distinguishing between state and municipal responsibilities. Resultantly, a family is taken from the EAE in Mannheim, to a central distributing place of the state in Karlsruhe, only to be taken back to Mannheim, where it will be sheltered in municipal accommodation.

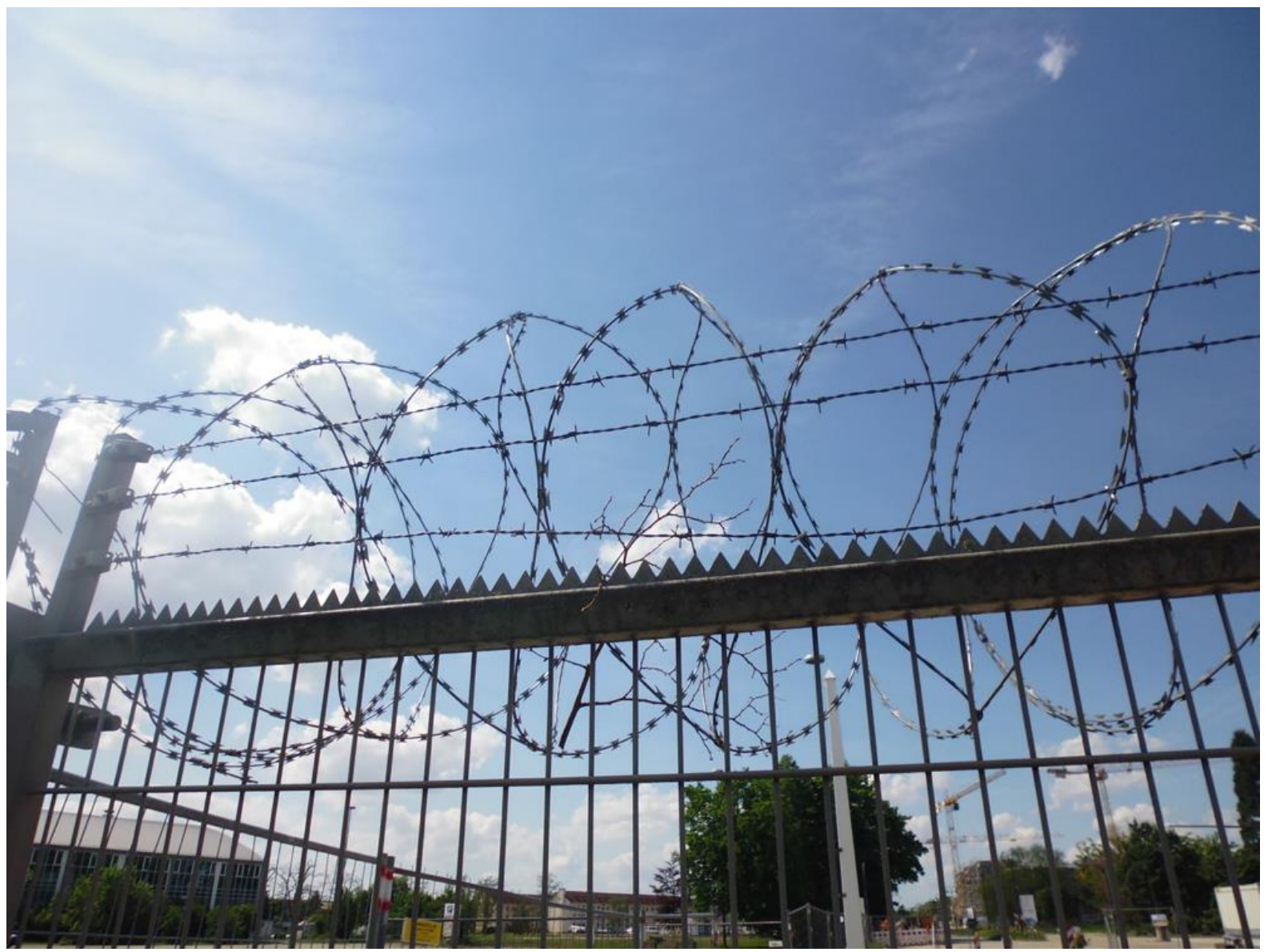


Transfers of refugees to other centres, to other nodes in the reception system, constitute the most important event in the centre. A list announcing the transfer dates of individuals is pinned on a blackboard outside the state's office. Everyone is required to check it daily, as

610 transfers are only announced one day prior to departure and people are not informed individually. The transfer is thus the one moment that everyone is waiting for, rendering BFV equally a 'waiting room' (Agier 2011, 72). In addition to this temporal uncertainty, residents have no influence over their destination; a practice that separates migrants from communities or familiar environments and thus local forms of support and could end in a small village or a metropolis. Talking to people at the blackboard discloses the frustration and confusion about the unpredictable nature of the transfer system, enabling movement for some, but containing it for others, based on what seems arbitrary and haphazard, as this observation elucidates:

Today, transfers are announced for Thursday: 11 Gambians, 2 from Cameroon, 2 Nigerians. I start talking to two young men at the board. Both are from Gambia, both have been here for 9-10 months. One of them is now being transferred to Böblingen, the other one needs to stay. "Man, it's really shit here. The food is shit, the life is shit, we have nothing to do. But Böblingen is close to Stuttgart, I know it. It will be different." The other one seems upset: "Why not? Why not? I've been here for one year. It's not fair." (Field notes, 20 June 2017)

Conversely, while on one hand residents are eagerly awaiting the transfers for months, on the other they can also be arranged within days. That is, the transfers serve as techniques of power, actively used to prevent the formation of collective political subjects in the centre (Tazzioli 2016). In a staff meeting, a senior state official stressed the need to 'draw a line for 630 trouble makers and take them out of their social habitat' (Field note, May 25 2017) inducing the transfer of several individuals to nearby camps, purposefully destroys social connections between the inhabitants. The backdrop to this decision was multiple tensions between the private security staff and a group of inhabitants complaining about the quality of food and 
racist attitudes towards them. Some were active members of the residents' council, founded to represent the interests of the inhabitants. ${ }^{11}$

Considering the ways containment is achieved through movement in BFV, what comes to mind is Rodgers and O’Neil's notion of 'infrastructural violence' (2012), exposing how certain infrastructural activities are the material instruments to exclude actors in

640 contemporary cities. Indeed, it alludes to the 'active' side of infrastructural violence (ibid. 407), which implies a clear intent in that it is designed to be violent, using the capacity of 'infrastructure to regulate normative social and territorial relations' (ibid.).

\section{$\underline{\text { An Internal 'Exterritorial Situation' }}$}

645 The final point concerns the double management of BFV, resulting from the two-tiered reception system in Germany. As elaborated earlier, due to German reception policy framework, BFV is managed by the federal state of Baden-Württemberg, whereby its legal status aims to disentangle it from the city of Mannheim. One planning official thus called it an 'extraterritorial situation' (Interview 006) to the city. This conceived extraterritoriality significantly impacts the city’s humanitarian gesture towards migrants.

For instance, while the municipality found extremely creative ways to respond to the newcomers by creating a specific refugee budget and a new post for a 'refugee coordinator' following the influx in 2015, largely in charge of organising the many enthusiastic volunteers wanting to help, channelling these forces into practice was rendered difficult because

\footnotetext{
${ }^{11}$ Negative news like this hardly make it to the public but, for instance, in January 201670 residents in BFV wrote an open letter complaining of poor medical supplies and racism among the security staff (The Guardian, 2016).
} 
'at first nobody was allowed into the Erstaufnahme [...] so the aim was not to do too much, they [the refugees] should not have the feeling they arrived in Mannheim [according to the state]. '(Interview 004)

Indeed, repeatedly it was stressed by informants that the state of Baden-Württemberg not

660 sufficiently included the city in the planning process of BFV (Interview 009; Rhein-NeckarZeitung 2017). Concurrently, staff members are not responsible for what is happening 'outside', establishing an apparent disconnection between the management of the centre and the city, as this comment by a social worker on site illustrates:

'So the responsibility of Benjamin Franklin stops at the gate. That's where all actors 665 [working on the site] are out.' (Interview 003)

A productive infrastructural site to reveal this political incongruity is the highway B38 running parallel to the centre, as illustrated in the introduction of this paper. It showed how, despite the centre's connectedness at the level of its physical infrastructure to the city centre, the way it is administered as a space of the federal state and as such disconnected from the

670 city in terms of its management. The highway thus serves as an infrastructural space of this dis/connection, deeply implicated in the way refugees in BVF experience the centre's relationship with the city. 


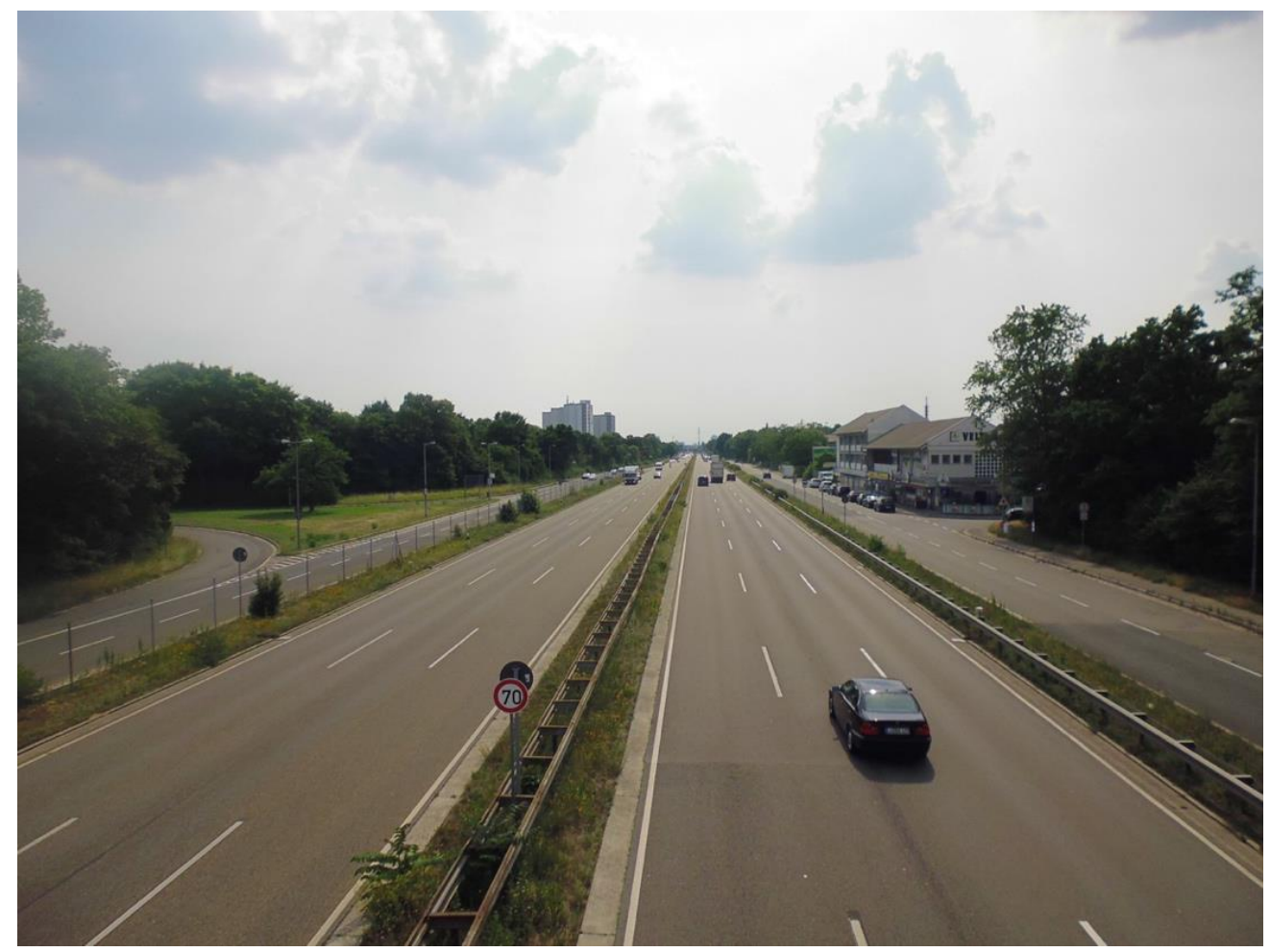

BFV is not far from Mannheim's city centre. It is approximately $9 \mathrm{~km}$ to reach the city's central market place. It is not possible to compare its isolation to other centres in places that might by way further away from urban centres. However, it is striking that this spatial

680 proximity is so contradictory to its residents' experience of the city, suggesting, perhaps, that we should see the reception centre as central, rather than peripheral, as this final comment by a social worker illustrates:

In the beginning, when I first entered the centre, I was shocked that some of the people I talked to did not know they were living in the city of Mannheim, in our city. They did not know where they lived.' (Interview 004) 
The analysis of the reception centre in Mannheim as infrastructures of reception advanced an understanding of the spatial politics of refuge, revealing the governance of this humanitarian space and its ambiguous relationship with the city. Contextualising Mannheim has shown that urban reception infrastructures are embedded in a national asylum policy framework, dictating tight mobility restrictions for asylum seekers in Germany. However, examining how these regulations play out in the actual spaces of migration in BFV has revealed that national legislations are regularly crisscrossed, a practice tolerated at the local level. Furthermore, focusing on the specific urban process at play in Mannheim, i.e. the transformation of the

700 former US-military barracks, exposed the political nature of reception infrastructures: Pinpointing towards the double-edged nature of its management, namely the insular position the reception centre holds between the municipality and the federal state, revealed a complex spatial-political struggle around the humanitarian space of the reception centre, rendering the reception gesture of the city of Mannheim a product of risk-benefit calculations for a local development scheme.

Further, attending to the micro practices of the reception centre, zooming into the daily infrastructural patterns of BFV by focusing on its socio-technical settings and thus revealing the inherent power relations of humanitarianism: attention to the materiality of the place exposed it as a space of humanitarian government that is always tightly entangled with security measures, an infrastructure that achieves containment by movement and, lastly, revealed its de-facto connectedness to the city of Mannheim, even though its legal status renders it an exclusive state-space. Engaging with the pressing contemporary problematics of refuge and its spatial semantics infrastructurally demonstrated how people and social forms 
715 partake in and are shaped by multiple systems and forces, themselves contingent and shifting, all with variable degrees of agency. Overall, then, the conceptualisation of infrastructures of reception helps to advance an understanding of the political nature of urban reception systems by unravelling how they - potentially and actually - make the city. Infrastructures of reception emerge not just as material embodiment of the ambiguities of humanitarianism, but

720 as their complicit and instrumental medium. This is to the extent that the material organisation and spatiality it forms do not only reflect, but also reinforce social orders, thus becoming a contributing factor in the reoccurring forms of containment, suspension and control recognising the entanglement of politics and infrastructure.

725 What appears assuring and productive about the infrastructural approach taken is the possibility to steer it towards practical, material recommendations, which could potentially improve the lives of those who are pressured by the city (Rodgers \& O’Neill 2012,6). It not only calls upon the social responsibility of the making of the political spaces of refuge but importantly directs action towards their realisation. How then is it possible to move from a de

730 facto connectedness, towards 'forms of ethical and political recognition, responsibility and inclusion that operate on the same level' (Ferguson 2012:562)?

Infrastructures of reception should be apprehended as an urban practice entangled with practices of power. This can strengthen the idea that the design of humanitarian spatialities such as reception centres not only encompasses the satisfaction of material needs, but fundamentally also recognises the socio-political requirements that are at stake, blurring the lines of the humanitarian categories produced by the German government. This should involve the participation of the residents and the 'managing actors', i.e. the government and the city, embracing the responsibility of the inevitable production of new relations and 
740 networks, enabling the formation of new communities and identities through the design processes at play in the provision and construction of refuge spaces in cities.

We hoped to have contributed to appreciate the work of infrastructure more visible moving to a 'new optical field' (Chattopadhyay 2012) in which infrastructure is a politics and in this

745 case a politics of reception. Therefore makes it possible to think about different mode of making cities and constructing urbanisms. 


\section{References}

Agier, M. 2010. 'Humanity as an Identity and Its Political Effects (A Note on Camps and Humanitarian Government)'. Humanity: An International Journal of Human Rights, Humanitarianism, and Development. 1(1). 29-45.

Agier, M. 2011. Managing the Undesirables: Refugee Camps and Humanitarian Government. Cambridge: Polity Press.

Amin, A. 2014. 'Lively Infrastructure'. Theory, Culture \& Society. 31(7-8). 137-161.

Angelo, H. \& Hentschel, C. 2015. 'Interactions with infrastructure as windows into social worlds: A method for critical urban studies: Introduction’. City. 19(2-3). 306-312.

Appadurai, A. 2015. 'Foreword' in S Graham \& C McFarlane (eds.). 2015. Infrastructural Lives: Urban Infrastructure in Context. London, New York: Routledge. pp.xii-xiii.

Appel, HC., Anand, N. and Gupta, A. 2015. 'Introduction: The Infrastructure Toolbox'. 765 Theorizing the Contemporary, Cultural Anthropology website, September 14, 2015. [online]. Available at: https://culanth.org/fieldsights/714-introduction-the-infrastructuretoolbox [accessed 09/01/2017].

Aumüller, J., Daphi, P., Biesenkamp, C. 2015. Die Aufnahme von Flüchtlingen in den 770 Bundesländern und Kommunen. Robert Bosch Stiftung. [online]. Available at: http://www.boschstiftung.de/content/language $1 / \mathrm{html} /$ publikationen.asp?output=html\&action=detail\&guid=2 a 76f960-0b2f-4dc9-a7db-5aa8fa23fe7d\&language=de\&back=back [Accessed 5/07/2017].

775 Barry, A. 2006. 'Technological Zone'. European Journal of Social Theory. 9(2). 239-253.

Barry, A. 2016. 'Infrastructure and the Earth' in CB Jensen, P Harvey and A Morito (eds.). 2016. Infrastructures and Social Complexity: A Companion. London, New York: Routledge. pp. 187-198.

780

Bevan, R. 2006. The destruction of memory: Architecture at war. Chicago: University of Chicago Press.

Blommaert, J. 2014. 'Infrastructures of superdiversity: Convivality and language in an 785 Antwerp neighborhood'. European Journal of Cultural Studies. 17(4). 431-451.

Boano, C. 2011. "Violent spaces": production and reproduction of security and vulnerabilities'. The Journal of Architecture. 16(1). 37-55.

790 Braun, B.P. 2014. 'A New Urban Dispositif? Governing Life in an Age of Climate Change'. Environment and Planning D: Society and Space. 32(1). 49-64.

Brighenti, AM. 2014. The Ambiguous Multiplicities: Materials, Episteme and Politics of Cluttered Social Formations. Basingstoke: Palgrave Macmillan. 
795 Bundestiftung Baukultur. 2017. 'Konversion: Alte Fläche, Neue Nutzung'. Bundestiftung Baukultur. [online]. Available at: https://www.bundesstiftung-baukultur.de/konversionalte-flaeche-neue-nutzung [accessed 18/08/2017].

Butler, J. 2015. Notes Toward a Performative Theory of Assembly. Cambridge, MA: Harvard $800 \quad$ University Press. 2015.

Chattopadhyay, S. 2012. Unlearning the City: Infrastructure in a New Optical Field. Minnesota: University of Minnesota Press.

805 Collier, S. 2011. Post-Soviet Social: Neoliberalism, Social Modernity, Biopolitics. Princeton: Princeton University Press.

Coward, M. 2009. 'Network-Centric Violence, Critical Infrastructure and the Urbanization of Security’. Security Dialogue. 40(4-5). 339-418.

810

Cowen, D. 2017. 'Infrastructures of Empire and Resistance'. Verso Books website. January 25, 2017. [online]. Available at: http://www.versobooks.com/blogs/3067-infrastructuresof-empire-and-resistance [accessed 10/04/2017].

815 Dillon, M., Reid, J. 2009. The Liberal Way of War: Killing to Make Life Live. London: Routledge.

Easterling, K. 2012. 'Zone: The Spatial Softwares of Extrastatecraft'. Places Journal. [online]. Availalbe at: https://placesjournal.org/article/zone-the-spatial-softwares-of-

820 extrastatecraft/ [accessed 09/10/2018].

Easterling, K. 2014. Extrastatecraft. The power of Infrastructure space. London: Verso.

Ehrkamp, P. 2005. 'Placing identities. Transnational practices and local attachments of 825 Turkish immigrants in Germany'. Journal of Ethnic and Migration Studies. 31(2). pp. 345364.

Farias, I. \& Bender, T. (eds.). 2010. Urban Assemblages: How Actor-Network Theory Changes Urban Studies. London, New York: Routledge.

830

Fassin, D. 2007. 'Humanitarianism as Politics of Life'. Public Culture. 19(3). 499-520.

Fassin, D. 2012. Humanitarian Reason: A Moral History of the Present. Berkeley; London: University of California Press.

Fauser, M. 2017. 'The Emergence of Urban Border Spaces in Europe'. Journal of Borderland Studies. [online]. Available at: 10.1080/08865655.2017.1402195 [accessed 10/10/2018].

Ferguson, J. 2012. 'Structures of Responsibility’. Ethnography. 13(4) 558-562.

840

Foucault, M. 1984. 'Space, Power, Knowledge' in P Rabinow (ed.). 1984. The Foucault Reader. New York: Pantheon Books. pp. 239-256. 
Gandy, M. 2005. 'Cyborg Urbanization. Complexity and Monstrosity in the contemporary City’. International Journal of Urban and Regional Research. 29(1). 26-49.

Geis, W. \& Orth, AK. 2016. Flüchtlinge regional besser verteilen: Ausgangslage und Ansatzpunkte für einen neuen Verteilungsmechanismus. Institut der deutschen Wirtschaft Köln for Robert Bosch Stiftung. [online]. Available at: http://www.bosch-

850 stiftung.de/content/language1/downloads/IW_Gutachten_Regionale_Verteilung_von_Fluec htlingen.pdf [accessed]. 18/08/2017.

Graham, S. \& Marvin, S. 2001. Splintering Urbanism: Networked Infrastructures, Technological Mobilities and the Urban Condition. London, New York: Routledge.

855

Graham, S. \& McFarlane, C. (eds.). 2015. Infrastructural Lives: Urban Infrastructure in Context. London, New York: Routledge.

Graham, S. 2010a. 'Interview with Stephen Graham by Ignacio Farias' in I Farias \& T 860 Bender (eds.). 2010. Urban Assemblages: How Actor-Network Theory Changes Urban Studies. London, New York: Routledge. pp. 197-205.

Graham, S. 2010b. Disrupted Cities: When Infrastructure Fails. London, New York: Routledge.

865

Gray, N. \& Mooney, G. 2011. 'Glasgow's new urban frontier: "Civilising” the population of "Glasgow East"'. City: analysis of urban trends, culture, theory, policy, action. 15(1). 424.

870 Harvey, P. \& Knox, H. 2012. 'The Enchantment of Infrastructure'. Mobilities. 7(4). 521-536.

Hess, S. (et al.). 2016. Der lange Sommer der Migration: Grenzregime III. Berlin: Assoziation A.

875 Holmes, S. \& Castañeda, H. 2016. 'Representing the "European refugee crisis" in Germany and beyond: Deservingness and difference, life and death'. American Ethnologist. 43(1). $12-24$.

Janmyr, M. \& Knudsen, A.J. 2016. 'Recapturing Refugee Camps: Hybrid Spaces of 880 Humanitarianism'. Humanity - An International Journal of Human Rights, Humanitarianism, and Development. 7(3). 391-395.

Kalkmann, M. 2017. Country Report: Germany. European Council on Refugees and Exiles. [online]. Available at: http://www.asylumineurope.org/reports/country/germany [Accessed 885 5/07/2017].

Kamalipour, H. \& Peimani, P. 2015. 'Assemblage Thinking and the City: Implications for Urban Studies'. Current Urban Studies. 3. 402-408.

890 Katz, B. et al. 2016. Cities and Refugees - The German Experience. The Brookings Institute. [online]. Available at: https://www.brookings.edu/research/cities-and-refugees-the-germanexperience/ [accessed 10/06/2017]. 
Katz, I. 2017. 'The Global Infrastructure of Camps'. Insecurities: Tracing Displacement and Shelter. January 10, 2017. [online]. Available at: https://medium.com/@Insecurities [ccessed 10/04/2017].

Knox, H. 2017. 'Affective Infrastructure and the Political Imagination'. Public Culture. 29(282). 363-384.

900

Kreichauf, R. 2018. 'From forced migration to forced arrival: the campization of refugee accommodation in European cities'. Comparative Migration Studies. 6(7). [Open Access].

Kusenbach, M. 2003. 'Street phenomenology. The go-along as ethnographic research tool'.

905 Ethnography. 4. 455-485.

Larkin, B. 2013. 'The Politics and Poetics of Infrastructure'. Annual Review of Anthropology. 41 (1-378). 327-343.

Lebuhn, H. 2013. 'Local Border Practices and Urban Citizenship in Europe. City: Analysis of $910 \quad$ Urban Trends, Culture, Theory, Policy, Action. 17(1). 37-51.

Leigh-Star, S. 1999. 'The Ethnography of Infrastructure'. American Behavioral Scientist. 43(3). 337-391.

Mattes, A. \& Stadlmair, J. 2017. 'Challenges of democratic inclusion: Investigating the 915 politics of difference'. Austrian Journal of Political Science. 46(1). 1-6.

Meeus, B. et al. 2018. 'Migration and the Infrastructural Politics of Urban Arrival', in: B Meeus, K Arnaut, B van Heur. Arrival Infrastructures: Migration and Urban Social Mobilities. Basingstoke : Palgrave Macmillan. pp.1-32.

920

Müller, A. 2014. The Organisation of Reception Facilities for Asylum Seekers in Germany. Focussed Study of the German National Contact Point for the European Migration Network. [online]. Available at: https://ec.europa.eu/homeaffairs/sites/homeaffairs/files/what-we-

925 do/networks/european_migration_network/reports/docs/emnstudies/10a.germany_national_report_reception_facilities_en_final.pdf [accessed 18/08/2017].

MWPS. 2017.Konversion Mannheim: Franklin Geschichte. MWPS. [online]. Available at: 930 http://franklin-mannheim.de/franklin/geschichte [accessed on 24/08/2017].

Niemandsland Film. 2017. Trailer. [online]. Available at: http://niemandsland-film.com [Accessed 18/08/2017].

935 O’Neill, B. 2012. 'Of camps, gulags and extraordinary renditions: Infrastructural violence in Romania. Ethnography. 13(4). 466-486.

Oliver, K. 2017. Carceral Humanitarianism: Logics of Refugee Detention. Minnesota: University of Minesota Press.

940

Pichl, M. 2016. 'Die Asylpakete I und II: Der politische und rechtliche Kampf um die Asylrechtsverschärfungen' in S Hess, B Kasparek (eds.). Der langer Sommer der 
Migration: Grenzregime III. Assoziation A: Berlin. pp. 163-175.

945 Pro Asyl. 2015. 'Asylpaket I in Kraft: Überblick über die ab heute geltenden asylrechtlichen Änderungen'. Pro Asyl. 23 October 2015. [online]. Available at:

https://www.proasyl.de/hintergrund/asylpaket-i-in-kraft-ueberblick-ueber-die-ab-heutegeltenden-asylrechtlichen-aenderungen/ [accessed 18/08/2017].

950 Rajaram, PK. 2002. 'Humanitarianism and representations of the refugee'. Journal of Refugee Studies. 15. 247-64.

Rhein-Neckar-Zeitung. 2015. 'Tempolimit in Mannheim: Die B38 ist gefährlich für Flüchtlinge'. Rhein-Neckar-Zeitung. 24 Oktober 2015. [online]. Available at: https://www.rnz.de/nachrichten/mannheim_artikel,-Mannheim-Tempolimit-in-MannheimDie-B-38-ist-gefaehrlich-fuer-Fluechtlinge-_arid,136354.html [accessed on 29/08/2017].

Rhein-Neckar-Zeitung. 2017. 'Ankunftszentrum in Mannheim: Streit um Unterbringung von Flüchtlingen in Spinelli'. Rhein-Neckar-Zeitung. 28 August 2017. [online]. Available at: https://www.rnz.de/politik/suedwest_artikel,-ankunftszentrum-in-mannheim-streit-um960 unterbringung-von-fluechtlingen-in-spinelli-_arid,299007.htmll [accessed on 29/08/2017].

Ribas-Mateos, N. (ed.). 2016. Migration, Mobilities and the Arab Spring. Cheltenham: Edward Elgar Publishing Limited.

965 Rodgers, D. \& O’Neill, B. 2012. 'Infrastructural Violence: Introduction to the Special Issue'. Ethnography. 13(4). 401-412.

Sassen, S. 2012. 'When the center no longer holds: Cities as frontier zones'. Cities. [online]. Available at: http://dx.doi.org/10.1016/j.cities.2012.05.007 [accessed 10/10/2018].

Saunders, D. 2011. Arrival City: How the Largest Migration in History is Reshaping Our World. New York: Knopf Doubleday Publishing Group.

Schwarz, C. 2016. 'Refugees from Syria as 'guests' in Germany: the moral economy of 975 German refugee policy in 2014' in N Ribas-Mateos (ed.). 2016. Migration, Mobilities and the Arab Spring. Cheltenham: Edward Elgar Publishing Ltd. pp. 105-123.

Sigona, N. 2015. 'Campzenship: reimagining the camp as a social and political space'. Citizenship Studies. 19(1). 1-15.

980

Simone, A. 2004. 'People as Infrastructure: Intersecting Fragments in Johannesburg'. Public Culture. 16(3). 407-429.

Simone, A. 2012. 'Infrastructure: Introductory Commentary by AbdouMaliq Simone'.

985 Cultural Anthropology website. November 26, 2012. [online]. Available at: https://culanth.org/curated_collections/11-infrastructure/discussions/12-infrastructureintroductory-commentary-by-abdoumaliq-simone [accessed 10/04/2017].

Stadt Mannheim. 2015. 'Brief des Oberbürgermeisters an alle Bürgerinnen und Bürger zur 990 Flüchtlingssituation in Mannheim'. Stadt Mannheim. [Online]. Available at: https://www.mannheim.de/de/nachrichten/brief-des-oberbuergermeisters-an-allebuergerinnen-und-buerger-zur-fluechtlingssituation-in-mannheim [accessed 18/08/2017]. 
Tazzioli, M. 2015. 'Troubling Mobilities: Foucault and the Hold over "Unruly" Movements and Life-Time' in SFuggle, Y Lanci, M Tazzioli (eds.). 2015. Foucault and the History of Our Present. Basingstoke: Palgrave McMillan. pp. 159-175.

Tazzioli, M. 2016. 'The government of migrant mobs: Temporary divisible multiplicities in border zones'. European Journal of Social Theory. 1-18.

1000

The first author. 2017. 'Infrastructures of Reception: The Spatial Politics of Refuge in Mannheim, Germany'. Master's dissertation. The Bartlett School of Planning. University College London (unpublished).

1005 The Guardian. 2016. 'Sanctuary or ghetto? How Mannheim created a 'city within a city' for refugees'. The Guardian. 11 April 2016. [Online]. Available at:

https://www.theguardian.com/cities/2016/apr/11/refuge-cities-mannheim-germanyrefugee-crisis-sanctuary-or-ghetto [accessed on 29/08/2017]

1010 Ticktin, M. 2011. Casualties of Care: Immigration and the Politics of Humanitarianism in France. Berkeley, London: University of California Press.

Von Schnitzler, A. 2015. 'Ends'. Cultural Anthropology website. September 24, 2015. [online]. Available at: https://culanth.org/fieldsights/713-ends [accessed 18/08/2017].

1015

Walters, W. 2011. 'Foucault and Frontiers: Notes on the Birth of the Humanitarian Border' in U Bröckling, S Krasmann and T Lemke (eds.). 2011. Governmentality: Current Issues and Future Challenges. New York: Routledge. pp. 138-164.

1020 Walters, W. 2014. 'Migration, vehicles, and politics: Three theses on viapolitics'. European Journal of Social Theory. 18(4). 469-488.

Wendel, K. 2014. Unterbringung von Flüchtlingen in Deutschland. Regelungen und Praxis der Bundesländer im Vergleich. Förderverein PRO ASYL e. V. [online]. Available at:

1025 https://www.proasyl.de/wpcontent/uploads/2015/04/Laendervergleich_Unterbringung_2014-09-23_01.pdf_[accessed $10 / 06 / 2017]$. 